ARTICLE

Received 27 Mar 2015 | Accepted 17 Jun 2015 | Published 24 Jul 2015

DOI: $10.1038 /$ ncomms8856

OPEN

\title{
Utilization of ancient permafrost carbon in headwaters of Arctic fluvial networks
}

\author{
Paul J. Mann', Timothy I. Eglinton², Cameron P. Mclntyre ${ }^{2,3}$, Nikita Zimov ${ }^{4}$, Anna Davydova4, \\ Jorien E. Vonk ${ }^{5,6}$, Robert M. Holmes ${ }^{7} \&$ Robert G.M Spencer ${ }^{8}$
}

Northern high-latitude rivers are major conduits of carbon from land to coastal seas and the Arctic Ocean. Arctic warming is promoting terrestrial permafrost thaw and shifting hydrologic flowpaths, leading to fluvial mobilization of ancient carbon stores. Here we describe ${ }^{14} \mathrm{C}$ and ${ }^{13} \mathrm{C}$ characteristics of dissolved organic carbon from fluvial networks across the Kolyma River Basin (Siberia), and isotopic changes during bioincubation experiments. Microbial communities utilized ancient carbon (11,300 to $>50,000{ }^{14} \mathrm{C}$ years) in permafrost thaw waters and millennial-aged carbon (up to $10,000{ }^{14} \mathrm{C}$ years) across headwater streams. Microbial demand was supported by progressively younger $\left({ }^{14} \mathrm{C}\right.$-enriched) carbon downstream through the network, with predominantly modern carbon pools subsidizing microorganisms in large rivers and main-stem waters. Permafrost acts as a significant and preferentially degradable source of bioavailable carbon in Arctic freshwaters, which is likely to increase as permafrost thaw intensifies causing positive climate feedbacks in response to on-going climate change.

\footnotetext{
${ }^{1}$ Department of Geography, Northumbria University, Newcastle Upon Tyne NE1 8ST, UK. ${ }^{2}$ Department of Earth Sciences, Geological Institute, ETH Zürich, 8092 Zürich, Switzerland. ${ }^{3}$ Department of Physics, Laboratory for Ion Beam Physics, ETH Zürich, 8093 Zürich, Switzerland. ${ }^{4}$ North-East Science Station, Pacific Institute for Geography, Far-Eastern Branch of Russian Academy of Science, Cherskiy, Republic of Sakha (Yakutia), Russia. ${ }^{5}$ Department of Earth Sciences, Utrecht University, Heidelberglaan 2, 3584 CS Utrecht, The Netherlands. ${ }^{6}$ Arctic Centre, University of Groningen, PO Box 716, 9700 AS Groningen, The Netherlands. ${ }^{7}$ Woods Hole Research Center, Falmouth, Massachusetts 02540, USA. ${ }^{8}$ Department of Earth, Ocean and Atmospheric Science, Florida State University, Tallahassee, Florida 32306, USA. Correspondence and requests for materials should be addressed to P.J.M. (email: paul.mann@northumbria.ac.uk).
} 
C limate-induced Arctic warming has led to increased soil temperatures, causing a succession of changes associated with permafrost degradation and widespread ground collapse or thermokarst, including deepening of the seasonally thawed surface active layer ${ }^{1,2}$ and alterations to watershed hydrology ${ }^{3,4}$. These changes threaten to destabilize ancient (Pleistocene-aged) northern circumpolar terrestrial permafrost, which contains vast quantities of organic carbon (OC) comprising as much as $50 \%$ of global below-ground soil carbon stocks ${ }^{5}$. Consequently, soil OC losses of up to $220 \mathrm{PgC}$ by 2100 are predicted across Arctic regions ${ }^{6,7}$, leading to large-scale mobilization of permafrost-derived OC into Arctic inland and coastal waters ${ }^{8}$.

The great majority of OC $(>80 \%)^{9}$ supplied to coastal seas from Arctic rivers is in the form of dissolved OC (DOC) and thus readily available to support microbial carbon demand during transit through fluvial networks ${ }^{10}$. Growing evidence exists from temperate and sub-tropical regions ${ }^{11-13}$ that older aged terrestrial carbon can be an important subsidy to microbial communities, yet the processing and fate of ancient Arctic permafrost OC throughout fluvial networks is currently unknown. Understanding the response of aquatic systems to future increases in permafrost-derived DOC is necessary for determining its effects upon global carbon cycling and predicting its export via high-latitude rivers.

Studies from major Arctic rivers show that higher-order fluvial systems contain predominantly young ( ${ }^{14} \mathrm{C}$-enriched) $\mathrm{DOC}^{14-17}$, suggesting that limited mobilization of permafrost has occurred to date or that it has been removed upstream. A number of studies focusing on lower-order and headwater streams provide evidence for ancient DOC mobilization ${ }^{18,19}$. Elucidating the fate of permafrost-derived DOC is crucial for establishing if on-going thaw is currently impacting Arctic fluvial networks and in determining whether its turnover may result in a positive carbon feedback to climate change ${ }^{7}$.

Here, we examine the quantity, age and source of the OC present, and constrain the nature of OC supporting microbial carbon demand with increasing water residence time through fluvial networks (higher order in the stream network). We base this work in the Kolyma River Basin, Siberia, which represents the largest global watershed (ca. $650,000 \mathrm{~km}^{2}$ ) completely underlain by continuous permafrost. The majority of this permafrost is comprised of frozen Yedoma, organic-rich (1-5\% carbon by mass) Pleistocene-aged deposits that can contain $50-90 \%$ ice content ${ }^{5,20}$. Yedoma-ice complexes measured in the Kolyma Basin suggest that permafrost carbon by mass concentrations are on the order of $1.5 \pm 1.4 \%$, with an average carbon inventory amounting to $14 \pm 8 \mathrm{~kg} \mathrm{~m}^{-3}$ (refs 21-23). Thawing Yedomaderived OC is thought to be highly susceptible to biological degradation in fluvial networks ${ }^{19,24}$, and has been proposed as a key feedback upon global climate ${ }^{20}$.

We first assess the initial age and bioavailability of DOC in streams and rivers throughout the basin using measurements of biologically degradable DOC (using DOC loss) and ${ }^{14} \mathrm{C}-\mathrm{DOC}$ measurements. We then determine the source and age of DOC subsidizing microbial demand throughout the network using simultaneous measurements of stable and radiocarbon signatures of DOC $\left({ }^{13} \mathrm{C}\right.$ and $\left.{ }^{14} \mathrm{C}\right)$ during short-term (28 days) bioincubation experiments. We show that a preferential loss of permafrostderived DOC occurs with increasing water residence and inland water transit time, despite similar initially modern DOC ages. Our results demonstrate that microbial communities selectively remove ancient OC during water transit throughout the fluvial network, with a potential to rapidly act as a positive feedback upon climate change with increasing permafrost thaw.

\section{Results}

Initial ${ }^{14} \mathrm{C}$-DOC age and proportion bioavailable DOC. We conducted 81 individual incubation experiments on samples from 19 streams and rivers throughout the Kolyma fluvial network, grouping by stream size and type (Fig. 1; Supplementary Table 1). Thaw streams, directly draining Yedoma outcrops, contained extremely high concentrations of DOC $(10,939 \pm 1,278 \mu \mathrm{M})$ that are highly depleted in ${ }^{14} \mathrm{C}\left(\Delta^{14} \mathrm{C}-883 \pm 41 \%\right.$; Fig. 2a). A large proportion of thaw stream DOC was utilized by microorganisms

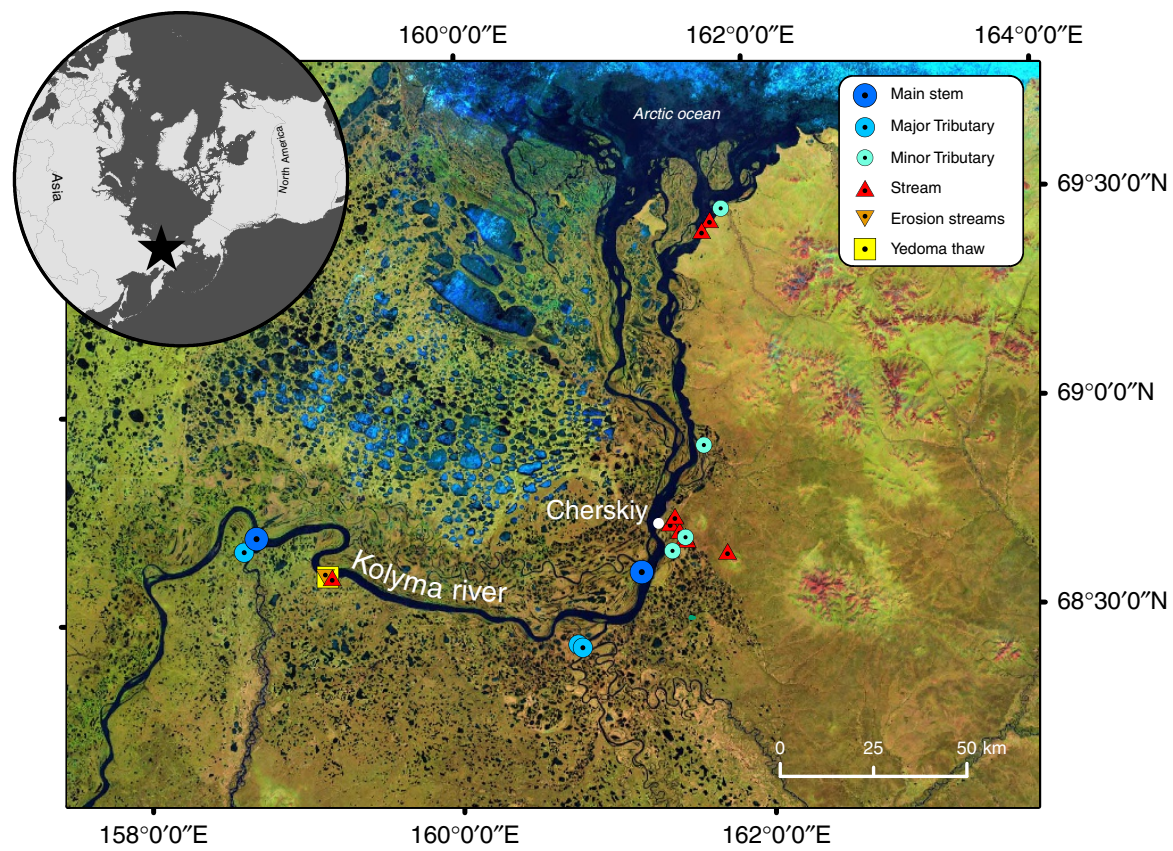

Figure 1 | Study site and sample locations. Location and type of waters collected throughout the fluvial network. Cherskiy and site of the Northeast science station is marked in white. Individual site latitude and longitude information is provided in Supplementary Table 1. 
$\left(\mathrm{DOC}_{\text {loss }}\right)$ during short-term $\left(28\right.$ days, $\left.20^{\circ} \mathrm{C}\right)$ incubations $(47 \pm 8 \%)$, confirming the high bioavailability of permafrostderived carbon in fluvial systems ${ }^{19,24}$ (Table 1; Supplementary Table 2). Mean DOC concentrations declined moving downstream through the fluvial network, yet proportions of DOC $_{\text {loss }}$ were similar (15-21\%) among all other stream and river waters (analysis of variance $P>0.05$, Table 1; Supplementary Table 2). Erosion-impacted streams that receive greater amounts of permafrost soil inputs via mechanical erosion of the stream banks contain ${ }^{14} \mathrm{C}$-depleted DOC $(-214 \pm 145 \%$; Fig. 2a), highlighting the strong potential for thermokarst processes to sporadically deliver aged OC to fluvial networks. By contrast, all other stream and river waters contained modern initial bulk DOC pools $\left(\Delta^{14} \mathrm{C}>-50 \%\right.$; Fig. $\left.2 \mathrm{a}\right)$, consistent with the majority of available radiocarbon data for DOC from major Arctic Rivers ${ }^{14,15,18}$

Radiocarbon age of DOC supporting microbial demand. Microbial communities in Yedoma thaw stream waters consistently utilized highly ${ }^{14} \mathrm{C}$-depleted DOC ( -750 to $-1,000 \%$ ), indicating that Pleistocene-age OC $\left(11,300\right.$ to $>50,000{ }^{14} \mathrm{C}$ years $)$ is intrinsically biologically labile and immediately available for microbial metabolism after mobilization to freshwaters (Fig. 2b).
Microbial demand in erosion-impacted streams was also supported by highly aged DOC $\left(\Delta^{14} \mathrm{C},-405 \pm 185 \%\right.$, Table 1$)$, demonstrating that microbial communities in waters containing mixed modern and ancient OC pools can preferentially utilize an older OC fraction (up to $10,000{ }^{14} \mathrm{C}$ years). Furthermore, despite similar modern initial bulk DOC ages among other stream and river waters, $\Delta^{14} \mathrm{C}$ values of the DOC utilized by microorganisms across these sites (that is, the fraction consumed during bioincubations) varied considerably $\left(\Delta^{14} C+300\right.$ to $-630 \%$; Fig. $\left.2 b\right)$, indicating a disconnect between bulk DOC age and the age of DOC fuelling microbial demand ${ }^{11,13}$. Modern $\left({ }^{14} \mathrm{C}\right.$-enriched $)$ DOC periodically utilized by microorganisms through the river network may have been delivered from soil pore waters that can contain high values of $\Delta^{14} \mathrm{C}-\mathrm{DOC}^{25}$ or may be caused by the upstream preferential loss of aged OC.

Source and radiocarbon age of DOC supporting microorganisms. We used a dual-isotope approach ${ }^{26}$ to examine the source and age of OC subsidizing $D_{\text {OOss }}$ throughout the stream network. We partitioned source contributions that most likely explained utilized $\Delta^{14} \mathrm{C}$ and $\delta^{13} \mathrm{C}$ values of $\mathrm{DOC}_{\text {loss}}$, assuming three dominant sources of DOC (contemporary terrestrial OC, permafrost-derived terrestrial OC and internally produced in situ OC) (Fig. 3a).
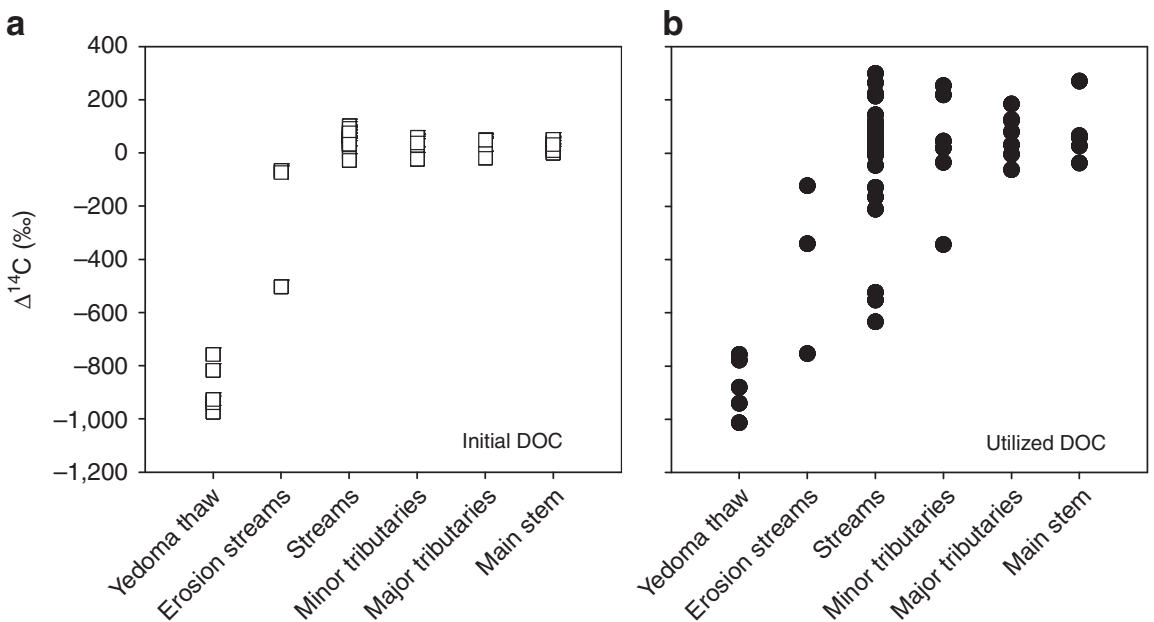

Figure 2 | Downstream $\Delta^{\mathbf{1 4}} \mathbf{C}$ DOC values. $\Delta^{14} \mathrm{C}$ values of (a) initial DOC, and (b) utilized DOC supporting microbial demand (DOC $\mathrm{C}_{\text {loss }}$ ) during bioincubations. $\Delta^{14} \mathrm{C}$ values of utilized DOC were calculated as outlined in equation (1) (see Methods). Table 1 displays mean values for initial and utilized DOC across sites and sample numbers for each site type.

Table 1 | DOC and isotope characteristics throughout the fluvial network.

\begin{tabular}{|c|c|c|c|c|c|c|c|c|c|c|}
\hline & $n$ & $\begin{array}{c}\text { Initial } \\
\text { DOC }(\mu M)\end{array}$ & $\begin{array}{c}\text { SUVA }_{254} \\
\left(\mathrm{mgC}^{-1} \mathrm{~m}^{-1}\right)\end{array}$ & $\begin{array}{c}\text { DOC }_{\text {loss }} \\
(\%)\end{array}$ & $\begin{array}{c}\text { Init. } \Delta^{14} C \\
(\%)\end{array}$ & $\begin{array}{c}O C_{\text {loss }} \\
\Delta^{14} \mathrm{C}(\%)\end{array}$ & $\begin{array}{c}\text { Mean }{ }^{O} C_{\text {loss }} \\
\text { age }\left({ }^{14} \mathrm{C} \text { years }\right)\end{array}$ & $\begin{array}{c}\text { Permafrost } \\
(\%)\end{array}$ & $\begin{array}{c}\text { Contemporary } \\
(\%)\end{array}$ & $\begin{array}{c}\text { In situ } \\
(\%)\end{array}$ \\
\hline Yedoma thaw & 5 & $10,939 \pm 1,278$ & $1.63 \pm 0.19$ & $47.2 \pm 7.6$ & $-884 \pm 41$ & $-873 \pm 48$ & 16,576 & $97.2 \pm 0.8$ & $1.7 \pm 0.5$ & $1.1 \pm 0.5$ \\
\hline Erosion streams & 3 & $2,503 \pm 518$ & $3.25 \pm 0.44$ & $17.5 \pm 4.9$ & $-214 \pm 145$ & $-405 \pm 185$ & 4,171 & $42.8 \pm 20.7$ & $56.4 \pm 20.7$ & $0.8 \pm 0.4$ \\
\hline Streams & 25 & $1,691 \pm 87.6$ & $3.44 \pm 0.11$ & $13.3 \pm 2.0$ & $51 \pm 6$ & $-21 \pm 50$ & 170 & $13.0 \pm 4.0$ & $85.9 \pm 4.0$ & $1.1 \pm 0.2$ \\
\hline Minor tributaries & 7 & $766 \pm 110$ & $3.56 \pm 0.19$ & $21.0 \pm 5.5$ & $25 \pm 13$ & $26 \pm 88$ & Modern & $5.7 \pm 3.5$ & $93.7 \pm 3.6$ & $0.6 \pm 0.2$ \\
\hline Major tributaries & 8 & $511 \pm 68$ & $4.03 \pm 0.08$ & $12.2 \pm 1.8$ & $40 \pm 3$ & $68 \pm 32$ & Modern & $0.6 \pm 0.1$ & $73.1 \pm 8.4$ & $26.3 \pm 9.9$ \\
\hline Main stem & 6 & $425 \pm 46$ & $3.67 \pm 0.10$ & $14.6 \pm 1.8$ & $22 \pm 9$ & $74 \pm 42$ & Modern & $0.7 \pm 0.1$ & $88.6 \pm 2.8$ & $10.7 \pm 4.4$ \\
\hline
\end{tabular}

DOC, dissolved organic carbon; OC, organic carbon

Mean initial DOC concentration, specific ultraviolet absorbance at $254 \mathrm{~nm}$ (SUVA 254 ), percent DOC loss over 28 days (DOC loss), calculated $\Delta^{14} \mathrm{C}$ value and mean radiocarbon age of DOC $\mathrm{C}_{\text {loss }}$ (using equation (1) in Methods). The sample size at each site type is provided ( $n$ ) and individual data are detailed in Supplementary Table 2. Mean percentage ( \pm s.e.m.) contribution of permafrost,

contemporary and in situ-derived DOC to DOC loss determined using the dual-carbon isotope mixing model. 

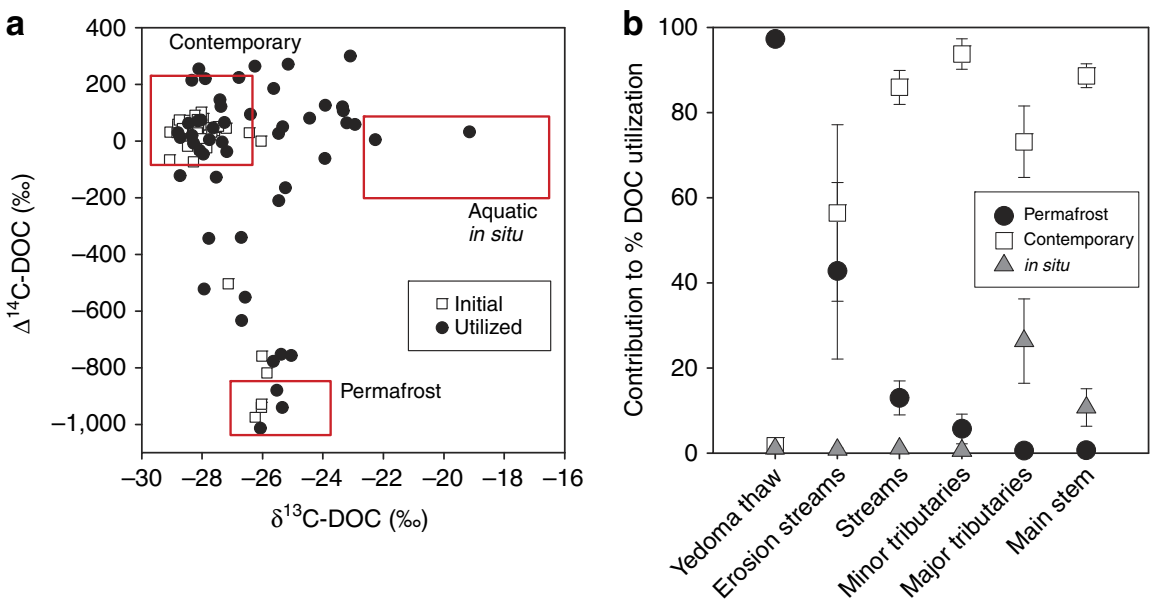

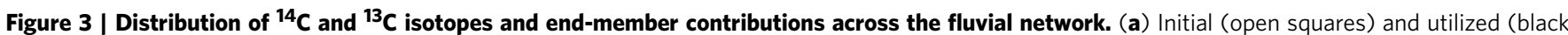
circles) $\Delta^{14} \mathrm{C}$ and $\delta^{13} \mathrm{C}$ values of DOC. Isotopic ranges of three contributing carbon sources are shown in red boxes (see Methods). (b) Mean percent ( \pm s.e.m.) contribution of each carbon source to the DOC utilized over bioincubations $\left(D O C_{\text {loss }}\right.$ ) in waters from differing site types.

Microbial demand in Yedoma thaw waters was almost entirely $(97.2 \pm 0.8 \%)$ supported by permafrost-derived OC, demonstrating that ancient DOC was highly bioavailable when present. Downstream, permafrost subsidized greater proportions of $\mathrm{DOC}_{\text {loss }}$ in higher-order erosion-impacted $(42.8 \pm 20.7 \%)$ and other small streams $(13.0 \pm 4.0 \%)$ as compared with minor tributary $(5.7 \pm 3.5 \%)$, major tributary $(0.6 \pm 0.1 \%)$ and mainstem waters $(0.7 \pm 0.1 \%)$ (Table 1$)$. This landscape pattern of declining permafrost contribution to $\mathrm{DOC}_{\text {loss }}$ through the fluvial network proved consistent across both years of investigation (2012 and 2013), showing that microbial demand in thaw streams and headwaters is consistently subsidized by significant proportions of permafrost OC. The fact that DOC character and age altered with increasing water residence time does not simply reflect catchment variability, as evidenced by identical patterns of DOC modernization in sub-basins within the larger Kolyma watershed. Furthermore, most sites drained similar soil and vegetation types, and spanned little elevation change within the Kolyma lowlands. Utilized $\Delta^{14} \mathrm{C}$ of $\mathrm{DOC}_{\text {loss }}$ increased exponentially $\left(r^{2}=0.72, P<0.001\right.$, Supplementary Fig. 1) relative to initial $\Delta^{14} \mathrm{C}$ values, suggesting that older OC fractions were rapidly and preferentially mineralized when present in bulk DOC (initial $\Delta^{14} \mathrm{C}<-20 \%$ ). Terrestrially derived contemporary OC contributed towards a minor proportion of $\mathrm{DOC}_{\text {loss }}$ in thaw waters $(1.7 \pm 0.5 \%)$, but comprised the main OC source ( $>55 \%$; Table 1 ) across stream and river waters, emphasizing the dominance of surface soil-water dynamics in determining bulk DOC character and thus biogeochemical processing and fate (Fig. $3 \mathrm{~b}$ ).

Environmental and compositional effects on ${ }^{14} \mathrm{C}$ utilization. Seasonal and spatial trends in OC bioavailability across fluvial networks can be controlled by variations in water temperature, inorganic nutrient availability and OC character ${ }^{24,27-30}$. To examine whether downstream variations in water temperature and inorganic nutrient concentrations influenced the fraction and age of DOC utilized, we conducted parallel experiments incubating waters at $4{ }^{\circ} \mathrm{C}$ and under nutrient-replete conditions.

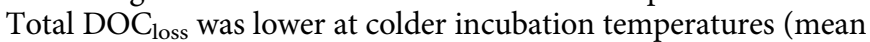
$Q_{10}=1.21 \pm 0.07$ ), but was not significantly different with respect to the mean $\Delta^{14} \mathrm{C}$ value of $\mathrm{DOC}_{\text {loss }}$ (paired $t$-test, $P>0.1$; Fig. $4 \mathrm{a}$ ). Bioenergetic constraints from lower water temperatures therefore did not consistently alter the DOC age or fraction utilized, implying that selective DOC loss continues during colder fall and winter periods, when greater contributions of older DOC could be expected ${ }^{17,18}$. Similarly, inorganic nutrient concentration did not significantly influence $\Delta^{14} \mathrm{C}$ values of $\mathrm{OC}_{\text {loss }}$ (paired $t$-test, $P>0.1$; Fig. $4 \mathrm{~b}$ ), indicating that stoichiometric differences cannot account for the observed downstream trends. Individual water samples displaying differences in the age of DOC utilized at colder temperatures, or under nutrient-replete conditions, all resulted in the loss of an older $\left({ }^{14} \mathrm{C}\right.$-depleted) DOC fraction. This implies that our results represent conservative estimates of permafrost OC loss along the aquatic continuum under our experimental conditions (Fig. 3a,b).

\section{Discussion}

Together, our findings indicate that terrestrial permafrost OC export is already underway and actively contributing to DOC turnover in Arctic fluvial networks. The presence of permafrost OC has previously gone undetected in fluvial networks due to the preferential loss of permafrost OC removing headwater signatures dominated by permafrost inputs ${ }^{31}$, combined with the historical dominance of field sampling on larger main-stem rivers ${ }^{15,32}$. In addition, the persistence of modern DOC sourced from vegetation and surface soils causes permafrost OC dynamics to be effectively masked when examining bulk initial OC alone ${ }^{33}$.

The composition of DOC in Arctic stream and river networks is expected to shift under future climate change scenarios ${ }^{1,2}$. Permafrost thaw is promoting greater groundwater and subsurface flow from Arctic and sub-arctic watersheds, likely resulting in the export of DOC characterized by lowermolecular weight compounds and a lower degree of aromaticity $3,4,17,27,31$. Across our sites, we observed a linear increase in the proportion of bioavailable carbon $\left(\mathrm{DOC}_{\text {loss }}\right)$ with decreasing DOC aromaticity as evidenced by lower SUVA $_{254}$ values $^{34,35}\left(r^{2}=0.50, P<0.001\right.$; Supplementary Fig. 2$)$, suggesting that increasing future permafrost contributions may promote enhanced microbial metabolism within Arctic fluvial networks. Furthermore, the microbial utilization of older DOC fractions was observed with decreasing OC aromaticity (Fig. 4c) and increasing $\mathrm{DOC}_{\text {loss }}\left(r^{2}=0.37, P<0.001\right)$, suggesting that DOC compositional changes will result in greater ancient carbon turnover. Heterotrophic metabolism and respiration is dependent on low-molecular weight DOC from thawing permafrost soils $^{24,28}$. The lower aromatic content and molecular weight of 

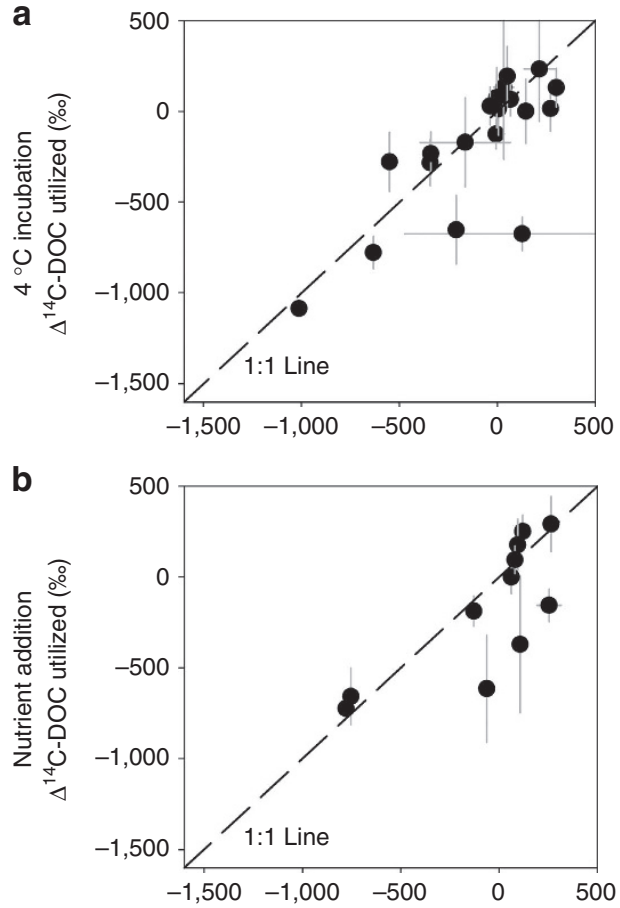

c

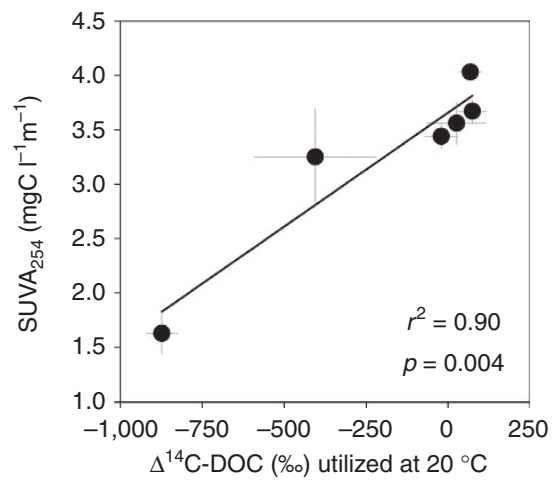

Figure 4 | Environmental and OC compositional controls on the age of carbon supporting freshwater microbial demand. $\Delta^{14} C$ values of DOC utilized ( \pm propagated s.e.m.) in parallel incubations conducted (a) at 20 and $4{ }^{\circ} \mathrm{C}(n=19)$ and (b) under ambient and nutrient-enriched conditions $(n=11)$. Dashed line represents 1:1 line. (c) $\Delta^{14} \mathrm{C}$ of mean DOC utilized across sites in relation to initial DOC aromaticity (inferred from SUVA 254 , see text for details). Decreasing SUVA $_{254}$ indicates declining DOC aromaticity $^{34}$.

permafrost-derived DOC may efficiently support bacterial production and favour higher carbon-use efficiencies ${ }^{36}$.

The microbial uptake of highly biologically available permafrost carbon can result in the preferential loss of ancient OC in aquatic networks, and the selective export of modern DOC to the ocean. Similar trends in the processing of permafrostderived DOC among fluvial networks of other major arctic rivers appear likely. All arctic watersheds are warming ${ }^{6}$ and exhibit similar trends and controls upon DOC export ${ }^{32}$. Freshwater discharge is also strengthening from at least the Eurasian arctic watersheds ${ }^{37,38}$. Yedoma permafrost in Alaska has also recently been shown to be highly bioavailable in good agreement with studies in Siberia ${ }^{19,24,39,40}$. Additional mechanisms, such as the selective burial of older aged OC, changing microbial community composition or preferential photodegradation of ancient OC may also play an important or complementary role in controlling permafrost turnover in northern high-latitude systems ${ }^{10,12,41}$. Photodegradation has been shown to influence surface water DOC processing in the Arctic ${ }^{41}$, yet it is currently unclear how sunlight affects the bulk age of DOC. Recognizing that modern bulk DOC signatures in Arctic rivers may disguise a rapidly cycling old $\mathrm{C}$ fraction, future efforts to detect the impacts of permafrost thaw should focus on headwater systems where the rapid removal and preferential biological utilization of ancient permafrost-derived DOC appears prevalent. As permafrost thaw accelerates ${ }^{1,6,8}$, it seems apparent that this will be accompanied by an increase in the amount of bioavailable DOC in aquatic networks, with aged DOC accounting for increased subsidies to aquatic microorganisms ultimately fuelling a positive feedback on climate.

\section{Methods}

Study area and sample collection. Surface water samples were collected directly from streams and rivers on several expeditions in 2012 and 2013 (Supplementary Table 1). Sampling concentrated during the months of August to October, when surface active layers are deepest and thus maximum export of permafrost-derived OC to inland waters is expected. Additional sampling soon after the spring ice-out period (June) provided insights during a period of minimal surface active layer thaw. We grouped sites by stream width, separating streams $(<1-5 \mathrm{~m})$, minor $(>5$ to $\leq 200 \mathrm{~m}$ ) and major tributaries $(>200 \mathrm{~m}$ ), and the Kolyma main stem (Fig. 1). A small proportion of highly turbid ( $>100$ nephelometric turbidity units (NTUs)) upland streams visibly affected by active mechanical soil erosion were examined independently (erosion streams) from unaffected streams $(<100 \mathrm{NTU})$, thus providing more robust source determination ${ }^{26}$ (see the Isotope mixing model section). These streams were always small ( $<3 \mathrm{~m}$ width) and situated within active thermokarst zones with mixed vegetation covered and exposed yedoma banks.

Stream temperature was measured in the field (YSI multi-meter) and sample turbidity immediately upon return to the laboratory (Hach 2100Q). Waters were filtered through pre-combusted glass fibre filters $(0.7 \mu \mathrm{m})$ on the day of collection using a combusted glass filtration system. After filtration, waters were immediately transferred into pre-combusted amber glass vials ( $40 \mathrm{ml}$ vials, $\sim 35 \mathrm{ml}$ water) leaving a headspace. Triplicate aliquots for initial DOC concentration were immediately acidified (trace element grade $\mathrm{HCl}, \leq \mathrm{pH} 2$ ) and stored until analysis. Aliquots for $\delta^{13} \mathrm{C}$ and $\Delta^{14} \mathrm{C}$ were immediately stored frozen $\left(-20^{\circ} \mathrm{C}\right)$ in preleached, acid-cleaned HDPE bottles.

DOC and bioincubations. DOC was calculated as the mean of between three and five injections on a Shimadzu TOC-V where the coefficient of variance across measurements was $<2 \%$. Triplicate bioincubation DOC measurements were typically within $<5 \%$ of each other. The bioavailability of DOC ( $\mathrm{DOC}_{\text {loss }}$ ) was determined as the difference in triplicate measures of DOC before and after a 28-day laboratory incubation at $20 \pm 0.5^{\circ} \mathrm{C}$ or $4 \pm 1{ }^{\circ} \mathrm{C}$ containing the indigenous microbial community from each site. The absorbance of water at $254 \mathrm{~nm}$ was measured (Shimadzu UV-1800) and the specific ultraviolet absorbance $\left(\mathrm{SUVA}_{254}\right)$ determined as a proxy for aromaticity ${ }^{34}$. After bioincubation, waters were refiltered as above, and samples collected as before for DOC, $\delta^{13} \mathrm{C}$ and $\Delta^{14} \mathrm{C}$ analyses. Parallel bioavailability incubations conducted with nutrient-amended waters were supplemented with inorganic nitrate and phosphate $\left(\mathrm{KNO}_{3} / \mathrm{KH}_{2} \mathrm{PO}_{4}\right)$ according to Redfield ratio, resulting in nutrient-replete incubations in relation to ambient site nutrient concentrations. We used analysis of variance to test between site means and paired $t$-tests to compare parallel incubations results. All tests including Univariate regression and exponential fits were conducted in SPSS21 (IBM).

Stable and radiocarbon isotope analyses. $\delta^{13} \mathrm{C}$ analyses were conducted at the University of California, Davis Stable Isotope Facility and ${ }^{14} \mathrm{C}$ analyses at the Eidgenössiche Technische Hochschule (ETH) Zürich. ${ }^{13} \mathrm{C}$-DOC samples were analysed using an O.I. Analytical Model 1010 TOC analyzer (precision of $\pm 0.2 \%$ ) interfaced to a PDZ Europa 20-20 IRMS (Sercon Ltd). ${ }^{13} \mathrm{C}$-DOC measurements were calibrated against the $\delta^{13} \mathrm{C}$ values of KHP and IHSS Suwannee River humic acid in Milli-Q. Waters for ${ }^{14} \mathrm{C}$-DOC analyses were freeze-dried (Christ Alpha 2-4, LSC with a low-carbon vacuum hybrid pump, Vacubrand RC-6; Martin Christ, Labex Instrument $\mathrm{AB}$, Sweden) directly in pre-combusted $\left(850^{\circ} \mathrm{C} / 5 \mathrm{~h}\right)$ quartz tubes. Samples were acidified under $\mathrm{HCl}$ vapours to remove carbonates and flame sealed with pre-combusted $\mathrm{CuO}$ under vacuum. $\mathrm{CO}_{2}$ was cryogenically captured and quantified ( $\sim 30 \mu \mathrm{g}$ carbon) before measurement using a microscale radiocarbon dating system (MICADAS; http://www.ams.ethz.ch/instruments/micadas) and gas-feeding system ${ }^{42,43}$. Combusted NIST SRM 4990C oxalic acid was used as a standard for normalization, and blanks were determined using radiocarbon-free $\mathrm{CO}_{2}$ both at a concentration of $5 \% \mathrm{CO}_{2}$ in He. The modern oxalic acid standard was measured to better than $1 \%$ relative error and until samples were fully consumed. 
Radiocarbon contents are reported as $\Delta^{14} \mathrm{C}(\%)$ and ${ }^{14} \mathrm{C}$ age. All radiocarbon values are corrected for procedural blanks with the errors propagated. The isotopic signature $\left(\Delta^{14} \mathrm{C}\right.$ and $\left.\delta^{13} \mathrm{C}\right)$ of the utilized DOC fraction (DOC loss) was calculated using triplicate measurements of initial DOC $\left(\mathrm{DOC}_{\text {initial }}\right)$ and final DOC concentrations $\left(\mathrm{DOC}_{\text {final }}\right)$ alongside the associated change in isotopic composition using simple mass balance (equation (1)). Individual errors associated with multiple isotope measurements were propagated to assess error on $\delta^{13} \mathrm{C}$ and $\Delta^{14} \mathrm{C}_{\text {utilized. }}$.

$$
\begin{aligned}
\mathrm{DOC}_{\text {loss }} \times \Delta^{14} \mathrm{C}\left(\text { or } \delta^{13} \mathrm{C}\right)_{\text {utilized }}= & \mathrm{DOC}_{\text {initial }} \times \Delta^{14} \mathrm{C}\left(\text { or } \delta^{13} \mathrm{C}\right)_{\text {initial }} \\
& -\mathrm{DOC}_{\text {final }} \times \Delta^{14} \mathrm{C}\left(\text { or } \delta^{13} \mathrm{C}\right)_{\text {final }}
\end{aligned}
$$

Isotopic mixing model. Feasible contributions of three end-member sources (permafrost DOC, contemporary DOC and in situ autochthonous DOC) to $\mathrm{DOC}_{\text {loss }}$ at sites were calculated using a dual-carbon isotope mixing model solved using a Monte Carlo simulation approach. Monte Carlo simulations were conducted using the MIXSIAR package ${ }^{26}$ v2.1.2 (https://github.com/brianstock/ MixSIAR/releases) within the R programming environment (http://www.Rproject.org). MixSIAR is a Bayesian mixing model ${ }^{44}$ that allows the contributions of source end-members to isotope data to be estimated, taking into account the uncertainty in source values ${ }^{45}$ and model error ${ }^{46}$ (residual and process errors). A dual-isotope approach $\left({ }^{14} \mathrm{C} /{ }^{13} \mathrm{C}\right)$ was used to increase the accuracy of contribution estimates and to solve for three potential end-member sources.

We defined two separate terrestrial end-members to differentiate between contemporary OC pools (vegetation, surface soils and surface active layer) and permafrost-derived OC that is delivered to freshwaters via ground collapse, or thermokarst processes, bank erosion or deep groundwater flow. An in situ-derived DOC source from aquatic primary producers (for example, periphytic algae) was also included. End-member values of each DOC source were determined as outlined below with final mean values and ranges defined as follows: permafrost $\delta^{13} \mathrm{C}-26.3 \pm 1.3 \%, \Delta^{14} \mathrm{C}-940 \pm 84 \%$; contemporary $\delta^{13} \mathrm{C}-28.5 \pm 2.0 \%$, $\Delta^{14} \mathrm{C} 71.6 \pm 170 \%$; in situ autochthonous $\delta^{13} \mathrm{C}-19.8 \pm 3.0 \%$, $\Delta^{14} \mathrm{C}$

$-78.0 \pm 170 \%$. Error estimates on end-member sources incorporated the entire variance in source values, enabling MixSIAR to fit the most viable end-member source to the model fit ${ }^{26}$. To account for potential fractionation of $\delta^{13} \mathrm{C}$, the MIXSIAR package was run including discrimination factors set to $\pm 1 \%$. No fractionation was allowed for $\Delta{ }^{14} \mathrm{C}$ values.

Each experiment was treated as an individual 'random' event, and site type (yedoma thaw, erosion stream, stream, minor and major tributary and main-stem waters) was included as a 'random' effect ${ }^{47}$, which improved model fit (determined as a reduction in the Akaike information criterion). Site type $(\sigma$ site $=7.1)$ explained a greater variation in source than individual information alone ( $\sigma$ ind $=1.8$ ), indicating that the total variation in the source of DOC fuelling microbial demand was driven by location along the fluvial network. Here we present posterior mean contribution estimates ( \pm s.e.m) among sites (Table 1; Supplementary Table 2).

Isotopic end-member determination. The contemporary $\delta^{13} \mathrm{C}(-28.5 \pm 2.0 \%$; $n=14)$ and $\Delta^{14} \mathrm{C}(71.6 \pm 150 \% ; n=21)$ was derived from literature ${ }^{18}$ and unpublished data (http://arcticgreatrivers.org/data, Vonk et al., unpublished;Supplementary Table 3) collected during the months of May and June from a range of small streams and rivers from the Kolyma River Basin. Data were limited to the early spring period, when water flow is restricted to surface horizons and thus most likely contains a topsoil and vegetation signature. A larger error estimate was applied to the $\Delta^{14} \mathrm{C}$ end-member values to incorporate soil pore water-derived DOC that can be highly ${ }^{14} \mathrm{C}$ enriched ${ }^{25}$

The $\delta^{13} \mathrm{C}$ value of the permafrost end-member $(-26.3 \pm 1.3 \%$; $n=374)$ is taken from a recent review of Yedoma deposits across Siberia ${ }^{48}$ and was also recently used in a similar dual-carbon isotope model to determine relative contributions of Yedoma to the East Siberian Arctic Shelf ${ }^{49}$. The value closely aligns with other $\delta^{13} \mathrm{C}$ DOC values $(-25.7 \pm 0.3 \% ; n=7)$ measured in Yedoma thaw waters ${ }^{19}$ and soils $(-25.1 \pm 0.3 \% ; n=2)$ from the Kolyma River Basin $(>2 \mathrm{~m})^{50}$. The $\Delta^{14} \mathrm{C}$ value for permafrost OC was taken from a synthesis of Yedoma data as detailed in Vonk et al. (2012; Supplementary Table S4 and references herein $)^{49}$. This value $(-940 \pm 84 \% ; n=300)$ closely aligns with Yedoma permafrost thaw water DOC measured in the Kolyma River Basin ${ }^{19,33}$ $(-944 \pm 23 \% ; n=6)$. By using a maximum estimate for the old carbon permafrost end-member, we ensure conservative estimates of old C supply to stream and river waters.

The $\delta^{13} \mathrm{C}$ value of aquatic primary producers (for example, periphytic algae) is highly variable and difficult to assess, with literature values varying from -40 to $-10 \% 0^{51} . \delta^{13} \mathrm{C}$ end-member values were estimated using dissolved inorganic carbon measurements from the Kolyma River (Raymond et al., unpublished) $(-7.5$ to $-7.2 \%)$ and Lena River $(-4.0$ to $-3.5 \%)$, and periphytic OC $\delta^{13} \mathrm{C}$ $\left(-23.0\right.$ to $-16.6 \%$ ) calculated using an established relationship between $\delta^{13} \mathrm{C}$ of DIC and of epilithic algae from across 70 different streams and rivers spanning arctic and temperate environments ${ }^{52}$. This linear relationship was derived from direct measurements of herbivore $\delta^{13} \mathrm{C}$ and DIC $\delta^{13} \mathrm{C}$ values ${ }^{52}$ and demonstrated that a consistent fractionation (for example, 19 or $20 \%$ assumed fixed photosynthetic fractionation) did not accurately constrain $\delta^{13} \mathrm{C}$ of algae from DIC measurements in lotic systems. This resulted in a relative fractionation for this study ranging from 13.1 to $15.5 \%$. Our calculated $\delta^{13} \mathrm{C}$ for algae closely align with values measured in a single plankton bloom on the Pantileikha River within the Kolyma Basin of $-23.3 \%$ (ref. 53) and of the end-members calculated for marine OC in Vonk et al. ${ }^{49}$ of $-24 \%$. Both values lie within our end-member estimates once the model discrimination factor of up to $1 \%$ has been applied for $\delta^{13} \mathrm{C}$ fractionation. Phytoplankton should reflect the current $\Delta^{14} \mathrm{C}$ of DIC in waters. $\Delta^{14} \mathrm{C}$ of DIC from the Kolyma River ranged from -77.0 to $-79.0 \%$ (Raymond et al., unpublished), and was therefore adopted as the mean end-member value in the mixing model.

\section{References}

1. Jefferies, M. O., Richter-Menge, J. A. \& Overland, J. E. Arctic Report Card 2013 http://www.arctic.noaa.gov/reportcard (2013).

2. Romanovsky, V. E. et al. Thermal state of permafrost in Russia. Permafrost Periglac. Process 21, 136-155 (2010).

3. Smith, L. C., Pavelsky, T. M., MacDonald, G. M., Shiklomanov, A. I. \& Lammers, R. B. Rising minimum daily flows in northern Eurasian rivers: a growing influence of groundwater in the high-latitude hydrologic cycle. J. Geophys. Res. 112, G04S47 (2007).

4. Walvoord, M. A. \& Striegl, R. G. Increased groundwater to stream discharge from permafrost thawing in the Yukon River basin: Potential impacts on lateral export of carbon and nitrogen. Geophys. Res. Lett. 34, L12402 (2007).

5. Tarnocai, C. et al. Soil organic carbon pools in the northern circumpolar permafrost region. Global Biogeochem. Cycles 23, GB2023 (2009).

6. Schuur, E. A. G. et al. Expert assessment of vulnerability of permafrost carbon to climate change. Clim. Change 119, 359-374 (2013).

7. Schaefer, K., Zhang, T., Bruhwiler, L. \& Barrett, A. P. Amount and timing of permafrost carbon release in response to climate warming. Tellus B 63, 165-180 (2011).

8. Vonk, J. E. \& Gustafsson, Ö. Permafrost-carbon complexities. Nat. Geosci. 6, 675-676 (2013).

9. Dittmar, T. \& Kattner, G. The biogeochemistry of the river and shelf ecosystem of the Arctic Ocean: a review. Mar. Chem. 83, 103-120 (2003).

10. Battin, T. J. et al. Biophysical controls on organic carbon fluxes in fluvial networks. Nat. Geosci. 1, 95-100 (2008).

11. McCallister, S. L. \& Giorgio, P. A. Evidence for the respiration of ancient terrestrial organic $\mathrm{C}$ in northern temperate lakes and streams. Proc. Natl Acad. Sci. USA 109, 16963-16968 (2012).

12. Fellman, J. B. et al. Dissolved organic carbon biolability decreases along with its modernization in fluvial networks in an ancient landscape. Ecology 95, 2622-2632 (2014).

13. Caraco, N., Bauer, J. E., Cole, J. J., Petsch, S. \& Raymond, P. A. Millennial-aged organic carbon subsidies to a modern river food web. Ecology 91, 2385-2393 (2010).

14. Benner, R., Benitez-Nelson, B., Kaiser, K. \& Amon, R. M. W. Export of young terrigenous dissolved organic carbon from rivers to the Arctic Ocean. Geophys. Res. Lett. 31, L05305 (2004).

15. Raymond, P. A. et al. Flux and age of dissolved organic carbon exported to the Arctic Ocean: a carbon isotopic study of the five largest arctic rivers. Global Biogeochem. Cycles 21, GB4011 (2007).

16. Striegl, R. G., Dornblaser, M. M., Aiken, G. R., Wickland, K. P. \& Raymond, P. A. Carbon export and cycling by the Yukon, Tanana, and Porcupine rivers, Alaska, 2001-2005. Water Resour. Res. 43, W02411 (2007).

17. Aiken, G. R., Spencer, R. G. M., Striegl, R. G., Schuster, P. F. \& Raymond, P. A. Influences of glacier melt and permafrost thaw on the age of dissolved organic carbon in the Yukon River basin. Global Biogeochem. Cycles 28, 525-537 (2014).

18. Neff, J. C. et al. Seasonal changes in the age and structure of dissolved organic carbon in Siberian rivers and streams. Geophys. Res. Lett. 33, L23401 (2006).

19. Vonk, J. E. et al. High biolability of ancient permafrost carbon upon thaw. Geophys. Res. Lett. 40, 2689-2693 (2013).

20. Zimov, S. A., Schuur, E. \& Chapin, F. S. III Permafrost and the global carbon budget. Science 312 (2006).

21. Schirrmeister, L. et al. Fossil organic matter characteristics in permafrost deposits of the northeast Siberian Arctic. J. Geophys. Res. 116, G00M02-G00M16 (2011).

22. Strauss, J., Schirrmeister, L., Wetterich, S., Borchers, A. \& Davydov, S. P. Grain-size properties and organic-carbon stock of Yedoma Ice Complex permafrost from the Kolyma lowland, northeastern Siberia. Global Biogeochem. Cycles 26, GB3003 (2012).

23. Strauss, J. et al. The deep permafrost carbon pool of the Yedoma region in Siberia and Alaska. Geophys. Res. Lett. 40, 6165-6170 (2013).

24. Mann, P. J. et al. Evidence for key enzymatic controls on metabolism of Arctic river organic matter. Global Change Biol. 20, 1089-1100 (2014). 
25. Trumbore, S., Schiff, S. L., Aravena, R. \& Elgood, R. Sources and transformation of dissolved organic carbon in the Harp lake forested catchment: the role of soils. Radiocarbon 34, 626-635 (1992).

26. Stock, B. C. \& Semmens, B. X. MixSIAR GUI User Manual, version 1.0 http://conserver.iugo-cafe.org/user/brice.semmens/MixSIAR (2013).

27. O’Donnell, J. A., Aiken, G. R., Walvoord, M. A. \& Butler, K. D. Dissolved organic matter composition of winter flow in the Yukon River basin: implications of permafrost thaw and increased groundwater discharge. Global Biogeochem. Cycles 26, GB0E06 (2012).

28. Roehm, C. L., Giesler, R. \& Karlsson, J. Bioavailability of terrestrial organic carbon to lake bacteria: the case of a degrading subarctic permafrost mire complex. J. Geophys. Res. 114, G03006 (2009).

29. Wickland, K. P. et al. Biodegradability of dissolved organic carbon in the Yukon River and its tributaries: seasonality and importance of inorganic nitrogen. Global Biogeochem. Cycles 26, GB0E03 (2012).

30. Mann, P. J. et al. Controls on the composition and lability of dissolved organic matter in Siberia's Kolyma River basin. J. Geophys. Res. 117, G01028 (2012).

31. Spencer, R. G. M. et al. Detecting the signature of permafrost thaw in Arctic rivers. Geophys. Res. Lett. 42, 2830-2835 (2015).

32. Holmes, R. M. et al. Seasonal and annual fluxes of nutrients and organic matter from large rivers to the Arctic ocean and surrounding seas. Estuar. Coast. 35, 369-382 (2011).

33. Feng, X. et al. Differential mobilization of terrestrial carbon pools in Eurasian Arctic river basins. Proc. Natl Acad. Sci. USA 110, 14168-14173 (2013).

34. Weishaar, J. L. et al. Evaluation of specific ultraviolet absorbance as an indicator of the chemical composition and reactivity of dissolved organic carbon. Environ. Sci. Technol. 37, 4702-4708 (2003).

35. Spencer, R. G. M., Aiken, G. R., Wickland, K. P., Striegl, R. G. \& Hernes, P. J. Seasonal and spatial variability in dissolved organic matter quantity and composition from the Yukon River basin, Alaska. Global Biogeochem. Cycles 22, GB4002 (2008).

36. McCallister, S. L., Bauer, J. E. \& Cherrier, J. E. Assessing sources and ages of organic matter supporting river and estuarine bacterial production: a multipleisotope (d 14C, d 13C, and d 15N) approach. Limnol. Oceanogr. 1687-1702 (2004).

37. McClelland, J. W., Déry, S. J., Peterson, B. J., Holmes, R. M. \& Wood, E. F. A pan-arctic evaluation of changes in river discharge during the latter half of the 20th century. Geophys. Res. Lett. 33, L06715-4 (2006).

38. Peterson, B. J. Increasing river discharge to the Arctic ocean. Science 298, 2171-2173 (2002)

39. Abbott, B. W., Larouche, J. R., Jones, J. B., Bowden, W. B. \& Balser, A. W Elevated dissolved organic carbon biodegradability from thawing and collapsing permafrost. J. Geophys. Res. Biogeosci. 119, 2049-2063 (2014).

40. Vonk, J. E. et al. Dissolved organic carbon loss from Yedoma permafrost amplified by ice wedge thaw. Environ. Res. Lett. 8, 035023 (2013).

41. Cory, R. M., Ward, C. P., Crump, B. C. \& Kling, G. W. Carbon cycle. Sunlight controls water column processing of carbon in arctic fresh waters. Science 345, 925-928 (2014)

42. Synal, H.-A., Stocker, M. \& Suter, M. MICADAS: a new compact radiocarbon AMS system. Nucl. Instrum. Methods Phys. Res. B 259, 7-13 (2007).

43. Ruff, M. et al. Gaseous radiocarbon measurements of small samples. Nucl. Instrum. Methods Phys. Res. B 268, 790-794 (2010)

44. Moore, J. W. \& Semmens, B. X. Incorporating uncertainty and prior information into stable isotope mixing models. Ecol. Lett. 11, 470-480 (2008).
45. Ward, E. J., Semmens, B. X. \& Schindler, D. E. Including source uncertainty and prior information in the analysis of stable isotope mixing models. Environ. Sci. Technol. 44, 4645-4650 (2010).

46. Parnell, A. C., Inger, R., Bearhop, S. \& Jackson, A. L. Source partitioning using stable isotopes: coping with too much variation. PLoS ONE 5, e9672 (2010).

47. Semmens, B. X., Ward, E. J., Moore, J. W. \& Darimont, C. T. Quantifying interand intra-population niche variability using hierarchical Bayesian stable isotope mixing models. PLoS ONE 4, e6187 (2009).

48. Schirrmeister, L., Froese, D., Tumskoy, V., Grosse, G. \& Wetterich, S. in The Encyclopedia of Quaternary Science (ed. Elias, S. A.) 542-552 (Elsevier, 2013).

49. Vonk, J. E. et al. Activation of old carbon by erosion of coastal and subsea permafrost in Arctic Siberia. Nature 488, 137-140 (2012).

50. Dutta, K., Schuur, E. \& Neff, J. C. Potential carbon release from permafrost soils of Northeastern Siberia. Global Change Biol. 12, 2336-2351 (2006).

51. Ishikawa, N. F., Hyodo, F. \& Tayasu, I. Use of carbon-13 and carbon-14 natural abundances for stream food web studies. Ecol. Res. 28, 759-769 (2013).

52. Finlay, J. C. Stable-carbon-isotope ratios of river biota:Implications for energy flow in lotic food webs. Ecology 82, 1052-1064 (2001).

53. Vonk, J. E. et al. Preferential burial of permafrost-derived organic carbon in Siberian-Arctic shelf waters. J. Geophys. Res. Oceans 119, 8410-8421 (2014).

\section{Acknowledgements}

We thank all of the staff at the Northeast Science Station in Cherskiy for assistance with field sampling and laboratory work. Special thanks to Daniel Montluçon and Lukas Wacker for assistance with radiocarbon analyses. This work was funded by US NSF grants PLR-1500169, ANT-1203885 and 1044610.

\section{Author contributions}

R.G.M.S., R.M.H. and T.I.E. conceived the study. Sample collection and incubation set-up was conducted by P.J.M., R.G.M.S., N.Z., A.D. and J.E.V. Radiocarbon analyses of samples was conducted by P.J.M. with assistance from T.I.E. and C.P.M. The manuscript was written by P.J.M. and R.G.M.S. with assistance and comments from T.I.E., C.P.M., N.Z., A.D., R.M.H. and J.E.V.

\section{Additional information}

Supplementary Information accompanies this paper at http://www.nature.com/ naturecommunication

Competing financial interests: The authors declare no competing financial interests.

Reprints and permission information is available online at http://npg.nature.com/ reprintsandpermissions/

How to cite this article: Mann, P. J. et al. Utilization of ancient permafrost carbon in headwaters of Arctic fluvial networks. Nat. Commun. 6:7856 doi: 10.1038/ncomms8856 (2015).

This work is licensed under a Creative Commons Attribution 4.0 International License. The images or other third party material in this article are included in the article's Creative Commons license, unless indicated otherwise in the credit line; if the material is not included under the Creative Commons license, users will need to obtain permission from the license holder to reproduce the material To view a copy of this license, visit http://creativecommons.org/licenses/by/4.0/ 